\title{
The influence of the fertilizing system on the petroleum residues biodegradation on a preluvosoil under control polluted
}

\author{
Sabău N.C. ${ }^{1}$, Şandor Maria², Domuța C. ${ }^{2}$, Brejea R. ${ }^{1}$, Domuța Cr. ${ }^{1}$
}

Keywords: soil pollution, petroleum residues, biodegradation, fertilizing system;

Summary

The paper presents the partial results of researches regarding the agrochemical melioration of soils under control polluted by petroleum residues that took place at the Agricultural and Research and Development Station in Oradea, Bihor County.

The experimental device was made out of $1 \mathrm{~m}^{2}$ microparcels, spread out in subdivided parcels, in four repetitions, having tree factors: A - the pollution by crude oil from Suplacu de Barcău, B - the mineral fertilization, and C - the organic fertilization.

The experience was set out on a preluvosoil in the year 1993 and the soil was cultivated with millet in the first 3 years and with spring wheat in the last 7 years of research.

The researches carried out in Oradea had the objective of establishing the effects of the fertilizing system on the petroleum residue biodegradation on a preluvosoil under control polluted with crude oil from Suplacu de Barcău, Bihor County.

\section{INTRODUCTION}

Soil pollution with oil residue is a very complex phenomenon, determined by crude oil, salty water and derrick sludge, which are manifest, in our country, on a surface of land of over 50 mii ha, with preponderance lands with agricultural utilization (Sabău et al., 2002)

In the conditions of Bihor County, oil extraction, processing and transport of petroleum products took place at the sites in Suplacu de Barcău, Marghita and Oradea, which have nowadays stations for OMV company and Petrolsub S.A. Suplacu d Barcău Rafinery. It are estimated that this activities are determined an historical pollution of soils on about 250 ha, which requires melioration works. (Şandor et al., 2007)

For the conditions from Western Romania, Colibaş et al., 1995 published the first partial results of researches regarding yield losses in millet, after the first year of controlled pollution with different doses of crude oil, from Suplacu de Barcău on the preluvosoil from Agricultural Research and Development Station Oradea.

Sanjeet et al, 2001 uses an inoculum addition to stimulate in situ bioremediation of oily-sludgecontaminated soil.

The research carried out in the south of Romania (Toti et al., 2003) concerning the melioration of agricultural lands polluted by crude oil from extraction fields, have provided that the plant's average life expectation diminished after a pollution of $1 \mathrm{~kg} / \mathrm{m}^{2}(0,3 \%)$ oil residue in the ploughed layer.

Plants are used to remove metals through three mechanisms: phytoextraction, rhizofiltration, and phytostabilization. At sites contaminated with organic contaminants, plants are used for remediation of organic wastes in several ways: phytodegradation, rhizodegradation, and phytovolatilization. (Lan 2004)

The researches makes by Siciliano et al. 2003, have demonstrated that phytoremediation systems, respective cultivated plants increase the microbiological potential of rhizosphere soil by altering the functional composition of the microbial community. This change in composition was linked to specific functional genotypes with relevance to petroleum hydrocarbon degradation.

Later, Şandor et al., 2007 Şandor and Sabău 2007 and Sabău et al. 2009, publish the results of yields, of some parcels polluted under control, at the experimental field from the Agricultural Research and Development Station Oradea and some correlations between yields and crude oil concentrations.

\section{MATERIAL AND METHODS}

The researches carried out in Oradea have like objective the study of organic and mineral fertilizers effect on millet-hay yields, in the time of melioration process of a soil under control polluted with crude oil, from Suplacu de Barcău, Bihor County.

Taking in consideration that on Romanian territory, from the surface which are affected by pollution with petroleum residue and salty water, near a half $(49,4 \%)$ is occupied by luvisoils and the type soil preponderantly polluted with crude oil at Suplacu de Barcău is also luvosoil, the experience carried out at Agricultural Research and Development Station Oradea, was placed also on a luvisoil. (Florea and Munteanu, 2000)

\footnotetext{
${ }^{1}$ University of Oradea, Faculty of Environmental Protection, 26 Gen. Magheru St., 410048 Oradea; Romania, e-mail: nsabau@ uoradea.ro

${ }^{2}$ Faculty of Environmental Protection and Agricultural Research Development Station Oradea, Aradului St., Romania;
} 
The experiment looking "The agrochemical melioration of polluted by petroleum residue of soils" is an experiment having tree factors, the type $2 \times 4 \times 4$, with microparcels of $1 \mathrm{~m}^{2}$, set out randomized, in four repetitions after the system of subdivided parcels.

The studied factors are:

The factor A: Pollution by crude oil:

$\mathrm{a}_{1}$ - control unpolluted;

$a_{2}-$ polluted by crude oil, in concentration of $3 \%\left(91 / \mathrm{m}^{2}\right)$ on ploughed layer;

The factor B: Organic fertilizer:

$\mathrm{b}_{0}-0 \mathrm{t} / \mathrm{ha}$ manure;

$b_{1}-50 t /$ ha manure;

$\mathrm{b}_{2}-100 \mathrm{t} / \mathrm{ha}$ manure;

$\mathrm{b}_{3}-150 \mathrm{t} / \mathrm{ha}$ manure;

The factor C: Mineral fertilizer:

$$
\begin{aligned}
& \mathrm{c}_{0}-\mathrm{N}_{0} \mathrm{P}_{0} \mathrm{~K}_{0} \mathrm{~kg} / \mathrm{ha} ; \\
& \mathrm{c}_{1}-\mathrm{N}_{100} \mathrm{P}_{80} \mathrm{~K}_{70} \mathrm{~kg} / \mathrm{ha} ; \\
& \mathrm{c}_{2}-\mathrm{N}_{200} \mathrm{P}_{160} \mathrm{~K}_{140} \mathrm{~kg} / \mathrm{ha} ; \\
& \mathrm{c}_{3}-\mathrm{N}_{300} \mathrm{P}_{240} \mathrm{~K}_{210} \mathrm{~kg} / \mathrm{ha} ;
\end{aligned}
$$

The experimental device was carried out in 1993, at the same time with the experiment looking the study of different doses of petroleum residue effect on yields, being cultivated in the first tree years with millet and than in the next seven years with spring wheat, Speranța breed.

The climate characterization was made with help of the rainfall and air temperature registered by Oradea Weather Station, what is placed near the experimental field.

\section{RESULTS AND DISCUSSION}

The climate conditions, characterized by annual rainfall and air temperature, show that the average for the first three years studied have less rain with $77,5 \mathrm{~m}$ and was warmer with $0,5{ }^{\circ} \mathrm{C}$ than the multi annual average. (Table 1.)

Annual rainfall were between 503,5 $\mathrm{mm}$ in 1993 and $636,9 \mathrm{~mm}$ in 1995 , with deviations from the annual average of the first three years between $131,5 \mathrm{~mm}$ and $+1,9 \mathrm{~mm}$. The values of the rainfall show that the period analyzed had drought, and only in the last year the rainfall registered came close to the annual average.

The variation interval of the annual temperature was between $10,6-11,8{ }^{\circ} \mathrm{C}$, values registered in 1995 and 1994, with positive variations compared to the annual average, $0,1-1,3{ }^{\circ} \mathrm{C}$, indicating warmer years than the annual.

The average yields of the first tree research years

Table 1 Climate characteristics of research period, Oradea Weather Station (1993-1995)

\begin{tabular}{|c|c|c|c|c|c|}
\hline \multirow{2}{*}{$\begin{array}{l}\text { Nr. } \\
\text { crt. }\end{array}$} & Years & \multicolumn{2}{|c|}{ Rainfall } & \multicolumn{2}{c|}{ Temperatures } \\
\cline { 3 - 6 } & $\mathrm{mm}$ & $\begin{array}{c}\text { Diffe- } \\
\text { rence }\end{array}$ & ${ }^{\circ} \mathrm{C}$ & $\begin{array}{c}\text { Differe } \\
\text {-nce }\end{array}$ \\
\hline 1. & 1993 & 503,5 & $-131,5$ & 10,7 & $+0,2$ \\
\hline 2. & 1994 & 532,0 & $-103,0$ & 11,8 & $+1,3$ \\
\hline 3. & 1995 & 636,9 & $+1,9$ & 10,6 & $+0,1$ \\
\hline \multicolumn{2}{|c|}{$\begin{array}{c}\text { Average } \\
1993-1995\end{array}$} & 557,5 & $-77,5$ & 11,0 & $+0,5$ \\
\hline \multicolumn{2}{|c|}{$\begin{array}{c}\text { Multi annual } \\
\text { average }\end{array}$} & 635,0 & - & 10,5 & - \\
\hline
\end{tabular}

(1993-1995) in which the experiment was cultivated with millet, was included between 34,7 q/ha and 54,0 q/ha millet-hay on control not polluted variants while on the variants polluted by petroleum residue in $3 \%$ concentration between 30,3 q/ha and 48,0 q/ha millet-hay (Table 2.)

The average of yields in all variants with organic and mineral fertilization studied, was of de 40,2 q/ha millet-hay, in the case of the parcels under control polluted by petroleum residue, more small with $4,7 \mathrm{q} / \mathrm{ha}$ than the average of variants with mineral and organic fertilization not polluted, which is of $44,9 \mathrm{q} / \mathrm{ha}$.

The smallest yield is obtained in the variant polluted with $3 \%$ petroleum residue, without mineral and organic fertilization, it is of $30,3 \mathrm{q} / \mathrm{ha}$, more small than in not polluted variant, without mineral and organic fertilization of $4,4 \mathrm{q} /$ ha millet-hay.

Both in the variants unpolluted and in the variants polluted by petroleum residue, the biggest yields are obtained for the maximum doses of mineral fertilizer, $\mathrm{N}_{300} \mathrm{P}_{240} \mathrm{~K}_{210}$ and organic fertilizer, $150 \mathrm{t} / \mathrm{ha}$ manure, these being of 54,0 q/ha millet-hay and respectively 43,2 q/ha millet-hay, for the control unpolluted variants.

The agricultural yields of millet-hay, in the first tree years of observation have a general tendency of permanent growth.

The yield difference between the control parcels, not polluted and the parcels under control polluted by petroleum residue was of $-4,7 \mathrm{q} / \mathrm{ha}$, which after three years of experiment become not significantly statistically.

The positive yield differences, achieved of the organic fertilizer doses, was included between 2,0 and 9,4 $\mathrm{q} / \mathrm{ha}$, in the case of the control not polluted variants and respectively between 3,0 and 6,4 q/ha in the case of under control polluted variants. These differences are distinctively significant and very significant statistic, in unpolluted variants, for the doses of $100 \mathrm{t} / \mathrm{ha}$ and respectively $150 \mathrm{t} / \mathrm{ha}$ manure, while in the case of variants 
under control polluted with petroleum residue, the difference achieved by the same quantity of mineral fertilizer is only significant and distinctively significant

Table 2.

The average yields (1993-1995) of millet-hay (q/ha) in the variants with mineral and organic fertilizers in not polluted and polluted under control by petroleum residue $(3 \%)$ on ploughed layer, parcels

\begin{tabular}{|c|c|c|c|c|c|c|c|}
\hline Variants & \multicolumn{4}{|c|}{ C. Mineral Fertilization } & \multirow{2}{*}{$\begin{array}{c}\text { Average B } \\
\text { Organic } \\
\text { Fertilization }\end{array}$} & \multirow{2}{*}{$\begin{array}{c}\text { Differences } \\
\text { B factor } \\
\text { (q/ha) }\end{array}$} & \multirow[t]{2}{*}{ Signification } \\
\hline B. Organic Fertilization & $\mathrm{c} 0$ & $\mathrm{c} 1$ & $\mathrm{c} 2$ & c3 & & & \\
\hline \multicolumn{8}{|c|}{ a1 - not polluted } \\
\hline b0 & 34,7 & 39,4 & 43,1 & 45,8 & 40,7 & - & \\
\hline b1 & 37,8 & 40,2 & 45,6 & 47,2 & 42,7 & $+2,0$ & \\
\hline b2 & 40,6 & 45,5 & 48,6 & 49,5 & 46,1 & $+5,4$ & $* *$ \\
\hline b3 & 43,8 & 49,6 & 53,1 & 54,0 & $50,1 \mathrm{~S}$ & $+9,4$ & $* * *$ \\
\hline Average $\mathrm{C}$ & 39,2 & 43,7 & 47,6 & 49,1 & 44,9 & & \\
\hline $\begin{array}{c}\text { Differences } \\
\mathrm{C} \text { factor }(\mathrm{q} / \mathrm{ha})\end{array}$ & - & $+4,5$ & $+8,4$ & $+9,9$ & & & \\
\hline Signification & & $* * *$ & $* * *$ & $* * *$ & & & \\
\hline \multicolumn{8}{|c|}{ a $2-$ polluted with crude oil $3 \%$} \\
\hline b0 & 30,3 & 34,3 & 39,3 & 42,5 & 36,6 & - & \\
\hline b1 & 34,4 & 37,6 & 41,6 & 44,6 & 39,6 & $+3,0$ & \\
\hline b2 & 36,5 & 39,7 & 43,2 & 45,7 & 41,3 & $+4,7$ & $*$ \\
\hline b3 & 37,7 & 42,7 & 44,4 & 48,0 & 43,2 & $+6,4$ & $* *$ \\
\hline Average C: & 34,7 & 38,6 & 42,1 & 45,2 & 40,2 & & \\
\hline $\begin{array}{c}\text { Differences } \\
\mathrm{C} \text { factor }(\mathrm{q} / \mathrm{ha})\end{array}$ & - & $+3,9$ & $+7,4$ & $+10,5$ & $-4,7$ & & \\
\hline Signification & & $* * *$ & $* * *$ & $* * *$ & & & \\
\hline
\end{tabular}

\begin{tabular}{|c|c|c|c|}
\hline LSD & A x A & B x B & C x C \\
\hline $5 \%$ & 5,76 & 3,71 & 1,22 \\
\hline $1 \%$ & 13,3 & 5,21 & 1,63 \\
\hline $0,1 \%$ & 42,3 & 7,36 & 2,12 \\
\hline
\end{tabular}

The amounts of mineral fertilizer applied are determined the positive yield differences of 4,5 - 9,9 $q /$ ha in the control not polluted variants and of 3,9 - 10,5 q/ha millet-hay in the polluted variants, all of these being very significant statistically.

Analyzing the yield differences evolution achieved by organic and mineral fertilizer doses applied it remarks the constant positive effect of the mineral fertilizer doses, for that the yield increases are very significant statistically both in the not polluted variants and in the polluted variants, in all years of the research.

The manure big quantities haves distinctively significant and very significant effects for the control variants, and respectively significant and distinctively significant for the variants under control polluted by petroleum residue.

Therefore, the most important effect is registered by the mineral fertilizer doses that stimulates the microorganism activity and intensifies the biodegradation process.

In order to highlight the effect of the climate conditions from the years of the researches were carried out, the correlative links between millet yield and the main climate elements that contribute to crop formation, rainfall and temperature product (RT) were tested. (Figure 1.)

Both in not polluted variant and in under control polluted with crude oil in $3 \%$ concentration, the correlative links between annual rainfall and air temperature product $\mathrm{RT}\left(\mathrm{mm} \times{ }^{\circ} \mathrm{C}\right)$ and respectively millet-hay yields (q/ha) are polynomial, second degree, the type $\mathrm{Y}=\mathrm{aRT} \mathrm{RT}^{2}+\mathrm{b} \mathrm{RT}-\mathrm{c}$.

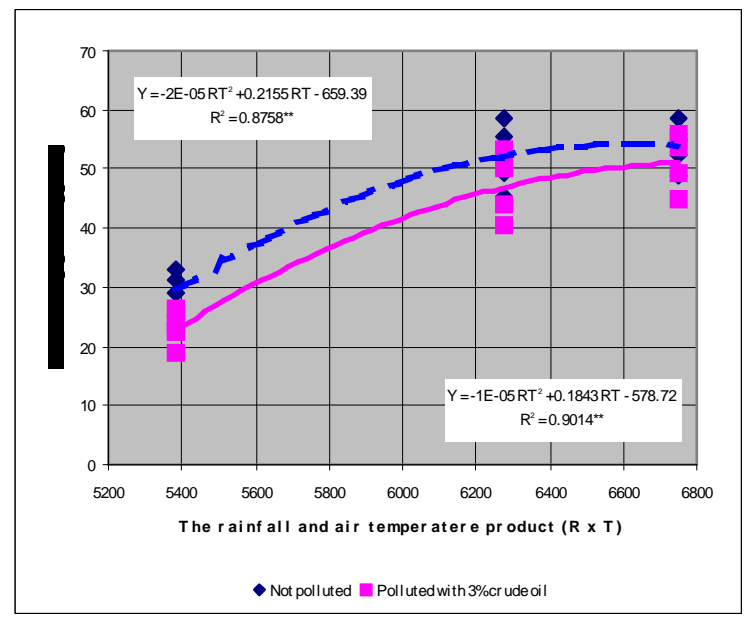

Figure 1. The influence of climate conditions on millet-hay yields under polluted and not polluted preluvosoil 
The yields achieved by the variants polluted with crude oil of $3 \%$ and variants not polluted increase with the increase in the rainfall and air temperature product for the same fertilizer system.

The correlative links thus established are very significant for both the variants studied, the correlation coefficient being more smaller, about 0,8758 for the not polluted variant and more bigger, about 0,9014 for the polluted with crude oil in $3 \%$ concentration variants.

The fact that the correlation coefficient of the link millet yields - rainfall and temperature product haves more bigger value in the case of polluted variants than in not polluted variants show that the climate conditions and fertilizer system haves an superior effect on yield on polluted variants.

\section{CONCLUSIONS}

The climate conditions, characterized by annual rainfall and air temperature, show that the average for the first three years studied have less rain with $77,5 \mathrm{~m}$ and was warmer with $0,5^{\circ} \mathrm{C}$ than the multi annual average.

In the same conditions of fertilizer system, the yield difference between the control parcels, not polluted and the parcels under control polluted by petroleum residue was of $-4,7 \mathrm{q} / \mathrm{ha}$, which after three years of experiment become not significantly statistically.

Analyzing the yield differences evolution achieved by organic and mineral fertilizer doses applied it remarks the constant positive effect of the mineral fertilizer doses, for that the yield increases are very significant statistically both in the not polluted variants and in the polluted variants, in all years of the research.

The manure big quantities haves distinctively significant and very significant effects for the control variants, and respectively significant and distinctively significant for the variants under control polluted by petroleum residue.

The correlative links established between annual rainfall and air temperature product $\mathrm{RT}\left(\mathrm{mm} \times{ }^{\circ} \mathrm{C}\right)$ and respectively millet-hay yields $(\mathrm{q} / \mathrm{ha}$ ) are very significant for both the variants studied, the correlation coefficient being more smaller, about 0,8758 for the not polluted variant and more bigger, about 0,9014 for the polluted with crude oil in $3 \%$ concentration variants.

Therefore, in the climate conditions of the first three years of research, the most important effect in millethay yields is registered by the mineral fertilizer doses, that stimulates the microorganism activity and intensifies the biodegradation process.

\section{REFERENCES}

1. Colibaş I., Colibaş Maria, Şandor Maria, 1995, Măsuri de ameliorare a solurilor poluate cu rezidii petroliere, Cum să cultivăm pământul în zona centrală din vestul țării, Stațiunea de Cercetări Agrozootehnice Oradea,

2. Colibaş I., Colibaş Maria, Tirpe Gh, 2000, Solurile brune luvice , caracterizare şi ameliorare, Ed. Mirton Timişoara;

3. Florea N., Munteanu I., 2000, Romanian Soils Taxonomy System SRTS - 2000 - "Alexandru Ioan Cuza" University Publishing House, Iași, pg. 99.

4. Lan Jun Kang , 2004, Recent developments of phytoremediation, Journal of Geological Hazards and Environmental Preservation, vol 15 , no 1 , pp.46-51;

5. Sabău N.C., Domuța C., Berchez O., 2002,: Geneza Degradarea şi Poluarea Solului, Partea a II-a Degradarea şi Poluarea Solului, Ed. Univ. din Oradea, 282, 240-242.

6. Sabău N. C., Sandor Maria, Domuta C., Brejea R., Domuța Cr., 2009, The estimation of degradated oil with the maximum of spring wheat yields on a preluvosoil from Oradea, Romania. International Symposia "Risk Factors for Environment and Foot Safety" \& „Natural Resources and Sustainable Development” 6-7 november, Analele Universității din Oradea, Fascicula Protecția Mediului.

7. Sanjeet Misha, Jeevan Jyot, Ramesh C. Kuhad, Banwari Lal, 2001, Evaluation of inoculum addition to stimulate in situ bioremediation of oily-sludge-contaminated soil, Applied and Environmental Microbiology, vol 67 (4), 1675 - 1681;

8. Siciliano S. D., Germida J. J., Kathy Banks and Greer Ch. W. , 2003, Changes in microbial community composition and function during a Polyaromatic Hydrocarbon phytoremediation field trial, American Society for Microbiology, Applied and Environmental Microbiology, vol 69, No 1, pg. 483-489;

9. Şandor Maria, Sabău N.C., Domuța C., Domuța Cr., Brejea R., 2007 The influence of soil pollution on agricultural crops, Joint International Conference on Long-term Experiments Agricultural Research and Natural Resources, Debrecen-Nyirlugos, 31May-1June, 608,304-311,

10. Şandor Maria, Sabău N.C., 2007, The influence of soil pollution by petroleum on millet yields - Analele Universității din Oradea, Fascicula Silvicultură, Vol XII, Anul XII, 319 - 326

11. Toti Mh., Dumitru Mh., Rovena Voiculescu Anca, Mihalache Mh., Mihalache Gabi, Constantinescu Carolina, 2003, Metodologia de biodegradare a solurilor poluate cu țiței, cu ajutorul microorganismelor specifice selecționate din microflora autohtonă, Edit. GNP Minischool, 164; 